\title{
Where the interesting species grow - remarkable records of lichens and lichenicolous fungi found during a Nordic Lichen Society meeting in Estonia
}

\author{
Ave Suija ${ }^{1}$, Inga Jüriado ${ }^{1}$, Piret Lóhmus ${ }^{1}$, Rolands Moisejevs² ${ }^{2}$ Jurga Motiejūnaité ${ }^{3}$, \\ Andrei Tsurykau ${ }^{4,5}$, Martin Kukwa ${ }^{6}$ \\ ${ }^{1}$ Institute of Ecology and Earth Sciences, University of Tartu, Lai 40, EE-51005 Tartu, Estonia. \\ E-mails: ave.suija@ut.ee; inga.juriado@ut.ee; piret.lohmus@ut.ee \\ ${ }^{2}$ Institute of Life Sciences and Technology, Daugavpils University, Parades 1A, LV-5401 Daugavpils, Latvia. E-mail: \\ rolands.moisejevs@biology.lv \\ ${ }^{3}$ Institute of Botany, Nature Research Centre, Žaliųjų Ežerų 49, LT-08406 Vilnius, Lithuania. \\ E-mail: jurga.motiejunaite@gamtc.lt \\ ${ }^{4}$ Department of Biology, Francisk Skorina Gomel State University, Sovetskaja 104, BY-246019 Gomel, Belarus. \\ E-mail: tsurykau@gmail.com \\ ${ }^{5}$ Department of Ecology, Botany and Nature Protection, Institute of Natural Sciences, Samara National Research \\ University, Moskovskoye road 34, RU-443086 Samara, Russia \\ ${ }^{6}$ Department of Plant Taxonomy and Nature Conservation, Faculty of Biology, University of Gdańsk, Wita Stwosza 59, \\ PL-80-308 Gdańsk, Poland. E-mail: martin.kukwa@ug.edu.pl
}

\begin{abstract}
In August 2019, the Nordic Lichen Society held its bi-annual meeting and excursion in south-western Estonia. The most remarkable findings of lichenized and lichenicolous fungi are recorded herewith, including nine new species (of them two lichenicolous), and one new intraspecific taxon for the country. Full species lists are provided for two notable locations, sandstone outcrop at the river Pärnu and an oak woodland in the Naissoo Nature Reserve, for which no previous data were available, to illustrate the importance of collective survey effort.
\end{abstract}

Kokkuvôte: 2019. a augustis toimus Eestis korraline, iga kahe aasta järel korraldatav Pôhjamaade Lihhenoloogide Ühingu kokkutulek ja ekskursioon. Artiklis anname ülevaate huvitavatest lihheniseerunud ja lihhenikoolsete liikide leidudest, sealhulgas üheksa (neist kahe lihhenikoolse) liigi esmaleiust Eestis ja ühe liigisisese taksoni esmaleiust. Lisaks esitatakse lihheniseerunud, lihhenikoolsete ja neile lähedaste seente täisnimekirjad, mis koostati kahe elupaiga - Tori Pórgu Maastikukaitseala liivakivipaljandi ning Naissoo Looduskaitseala koosseisu jääva Naissoo tammiku - kohta.

Keywords: new species, red-listed species, sandstone lichens, lichens in oakwood

\section{INTRODUCTION}

Nordic Lichen Society (NLS) is an organization of Nordic and Baltic lichenology aiming to share knowledge about lichen diversity between professionals and amateurs, and to educate next generation of researchers and lichen enthusiasts. The society holds bi-annual meetings and excursions mainly within member countries, and this time, the opportunity to organize the meeting was given to Estonia. During 6-10 August 2019, the $23^{\text {rd }}$ NLS meeting was held in south-western Estonia, consisting of four full-days field excursions to different habitats including coastal meadows and dry calcareous grasslands (alvars), sandstone and limestone cliffs, and different wooded habitats. In addi- tion to the field activities, Martin Kukwa from the University of Gdansk gave a lecture and held a workshop about sterile sorediate lichens containing usnic acid and xanthones.

The meetings bring together professionals and amateurs, and it is not a surprise that such gatherings notably raise the knowledge about biodiversity of the region (see, e.g., Thell et al., 2014; Holien et al., 2016). Several locally new lichenized or lichenicolous taxa have been recorded in recent international lichenological gatherings in Estonia: e.g., 17 (of them 10 lichenicolous) species in $14^{\text {th }}$ symposium of Baltic Mycologists and Lichenologists (BLS) (Halonen 
et al., 2000), 30 (13 lichenicolous) species in $5^{\text {th }}$ symposium of International Association of Lichenologists (IAL) (Aptroot et al., 2005) and 11 (6 lichenicolous) species in $17^{\text {th }}$ BLS symposium (Suija et al., 2009). To follow the idea, we asked the participants to survey and record as many lichenized and lichenicolous species as possible in two locations that represented little-studied habitat types in Estonia and from where previous data were missing. These habitats were middle-Devonian sandstone outcrops at the bank of the Pärnu river in the Tori Porrgu Landscape Reserve and oak woodland in the Naissoo Nature Reserve. In this paper, we present findings that (1) represent records of new, rare (with less than ten known localities), protected, red-listed or otherwise interesting species in Estonia from 12 locations that were visited during the meeting; and (2) provide full lists of lichens and lichenicolous fungi found in two study sites.

\section{MATERIALS AND METHODS}

\section{Study area}

South-West of Estonia and islands were chosen as the site for NLS meeting because of the richness of habitats valuable for lichens. During the 4-days meeting, we visited 12 locations (Fig. 1 ), covering oak-dominated woodlands, alvars, sandstone and limestone outcrops, a park around manor house, and old-growth forests. We made detailed surveys within limited time frame and compiled lists of lichenized and lichenicolous species for two locations (4 and 10 in the list below). Short descriptions of these habitats are given before their species lists.

\section{List of localities}

6 August 2019 (all localities in Pärnu County, Kihnu island)

1. Rootsiküla, north-western coast of Kihnu island, juniper shrubland in pasture and the granite stones at the sea, $58.10007^{\circ} \mathrm{N}$, $23.9764^{\circ} \mathrm{E}$

2. Rootsiküla, surroundings of Kihnu lighthouse, $58.09906^{\circ} \mathrm{N}, 23.96923^{\circ} \mathrm{E}$

3. Linaküla, wooded and coastal meadows with erratic boulders, $58.137699^{\circ} \mathrm{N}, 23.966962^{\circ} \mathrm{E}$

7 August 2019 (all localities in Pärnu County)

4. Tori community, Tori borough, Tori Põrgu (Tori Hell), sandstone outcrop at the river Pärnu, $58.483497^{\circ} \mathrm{N}, 24.816716^{\circ} \mathrm{E}$
5. Tori community, Tori borough, Tori cemetery, $58.483139^{\circ} \mathrm{N}, 24.81857^{\circ} \mathrm{E}$

6. Häädemeeste community, Nigula Nature Reserve, Nigula bog study trail, Salupeaksi bog island with old-growth broad-leaved deciduous forest, $58.018707^{\circ} \mathrm{N}, 24.68077^{\circ} \mathrm{E}$

8 August 2019

7. Saare County, Muhu island, Muhu community, Nõmmküla alvar, $58.66775^{\circ} \mathrm{N}$, $23.20594^{\circ} \mathrm{E}$

8. Saare County, Muhu island, Üügu Nature Park, Üügu cliffs and alvar, $58.67169^{\circ} \mathrm{N}$, 23. $2373^{\circ} \mathrm{E}$

9. Pärnu County, Lääneranna community, Puhtu-Laelatu Nature Reserve, Puhtu peninsula, old-growth broad-leaved deciduous forest, $58.55744^{\circ} \mathrm{N}, 23.55018^{\circ} \mathrm{E}$

9 August 2019 (all localities in Pärnu County)

10. Lääneranna community, Naissoo Nature Reserve, Naissoo oak forest mixed with some birches, $58.609033^{\circ} \mathrm{N}, 24.187376^{\circ} \mathrm{E}$

11. Lääneranna community, Nedrema Nature Reserve, Nedrema wooded meadow, $58.538175^{\circ} \mathrm{N}, 24.071151^{\circ} \mathrm{E}$

12. Pärnu, Tõstamaa borough, Tõstamaa park around Tõstamaa manor house, park with Acer platanoides, Larix europaea and Quercus robur, $58.343499^{\circ} \mathrm{N}, 23.997766^{\circ} \mathrm{E}$

\section{Species identification}

To confirm field identifications of some specimens, lichen substances were detected using thin layer chromatography method described in Orange et al. (2001) using solvent system A (AS, AT) and C (AT, MK), and DNA sequences were analyzed. DNA was extracted with a lysis procedure, amplified, purified and sequenced following the protocols in Voitk et al. (2020). The internal transcribed spacer (nuITS) region was amplified using the primer pair ITSOF / LA-W (Tedersoo et al., 2008). The voucher specimens are deposited in BILAS, DAU, GSU, TU, and UGDA, and the DNA sequences are accessible under UDB-codes through public Web output UNITE (http:/ / unite.ut.ee; Kõljalg et al., 2013). The distribution and rarity data were extracted from Data management and Publishing Platform PlutoF (https:// plutof.ut.ee).

\section{RESULTS}

During the 4-days field excursions, ten new taxa for Estonia were recorded, among them seven 


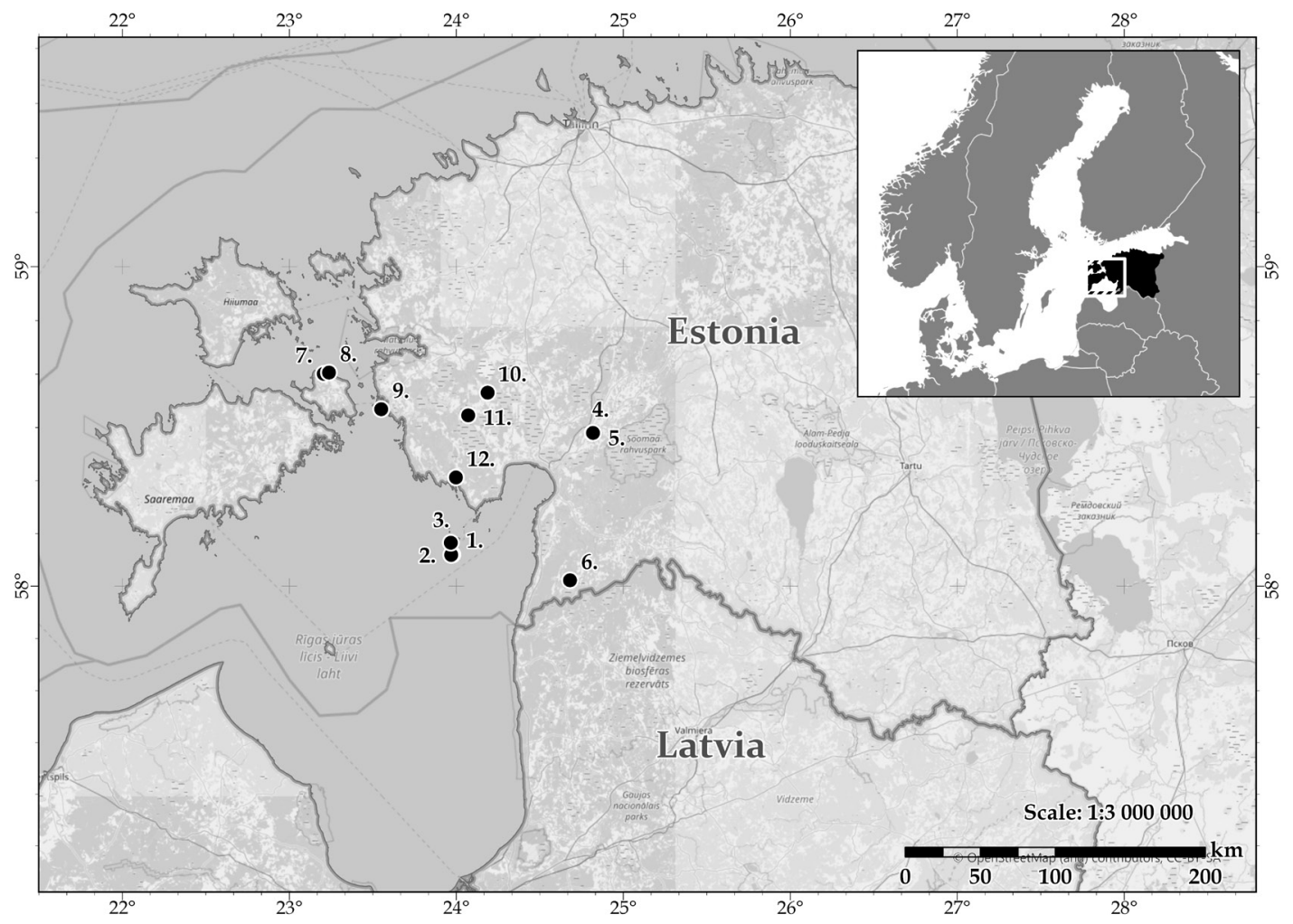

Fig. 1. The excursion sites of the $23^{\text {rd }}$ Nordic Lichen Society meeting in Estonia

lichenized species, one lichenized intraspecific taxon and two lichenicolous species. New localities were found for two threatened and three near-threatened species, according to the recent assessment of the threat status of Estonian lichens (Lõhmus et al., 2019). These species are: Enchylium limosum (red-listed category Vulnerable) and Lobaria pulmonaria (Vulnerable and III protection category), and Cladonia portentosa, Peltigera ponojensis and Sclerophora pallida (red-listed category Near Threatened, the latter also III protection category). New localities were found for 14 rare species, i.e species with up to 10 localities in Estonia. However, the frequency class sensu Randlane \& Saag (1999) changed for one lichenized - Ochrolechia bahusiensis and for two lichenicolous species - Abrothallus caerulescens (from rare to rather rare) and Trichonectria rubefaciens (from very rare to rare). During the excursions several protected and /or red-listed species were re-found in previously known localities, e.g. Lobaria pulmonaria in Nigula Nature Reserve and in Puhtu-Laelatu
Nature Reserve, Gyalolechia bracteata (Critically Endangered and III category), Placidium squamulosum (Near Threatened), Solorina saccata (Endangered and II category), Vulpicida juniperinus (Near Threatened) in Üügu Landscape Reserve on Muhu island.

\section{THE SPECIES LISTS}

Abbreviations of the names of collectors and determiners: AS - Ave Suija, AT - Andrei Tsurykau, IJ - Inga Jüriado, JM - Jurga Motiejūnaite, MK Martin Kukwa, PL - Piret Lõhmus, RM - Rolands Moisejevs. Species that are new to Estonia are marked in bold. Lichenicolous / algicolous species are marked with \#, non-lichenized species with + and indicator species of Woodland Key Habitat (WKH) (Anonymous, 2017) with !

\section{New, rare, protected, threatened and other- wise interesting species}

\# ABRothallus CAeRULESCEns I. Kotte - 7: on Xanthoparmelia conspersa on granite, AS (TU86821). 
This is the sixth locality for the species, and the first record in Muhu island.

Botryolepraria lesdainiI (Hue) Canals, Hern.Mar., Gómez-Bolea \& Llimona - 8: cave, $3 \mathrm{~m}$ from entrance, on limestone, MK 20494 (UGDA), TLC: lesdainin. The species usually occurs on strongly shaded calcareous rocks, where it grows directly on rocks or on calcareous bryophytes in rain-sheltered habitats, but sometimes it is found also on other substrates (Laundon, 1992; Baruffo et al., 2006; Kukwa \& Czarnota, 2008). So far B. lesdainii has been reported from Europe (e.g., Austria, Belgium, France, Germany, Italy, Finland, the British Isles, Poland, Portugal, Spain, Sweden) and North America (e.g., Laundon, 1992; Kümmerling \& Leuckert, 1993; Kukwa, 2000; Baruffo et al., 2006; Kukwa \& Czarnota, 2008).

Candelariella efflorescens R. C. Harris \& W. R. Buck (aggregate) - 10: on Quercus robur, leg. AT, det. MK (GSU). It is the single taxon in Candelariella which produces soredia and has polysporous asci. Sterile specimens are similar to C. reflexa which differs by its much larger, indistinctly effigurate thallus, crateriform soralia arising in the center of the thallus and larger soredia (Westberg, 2007). Candelariella efflorescens is a common species in Europe, North America, reported also from the Caucasus (Westberg, 2007; Gasparyan \& Sipman, 2016; Ismailov et al., 2017). The specimen is sterile but well-developed and has delimited punctiform soralia. However, according to Westberg \& Clerc (2012), when sterile, it is usually impossible to separate between C. efforescens and C. xanthostigmoides and therefore the specimen is referred here as C. efforescens aggregate.

Catillaria CRoatica Zahlbr. - 6: on Corylus avellana, MK 20475 and 20476 (UGDA), TLC: no lichen substances (traces of terpenoids are the same as in the analyzed bark). This is a rarely reported species as it is almost always found sterile, but can be distinguished by light greengrey, superficial, well or poorly developed to immersed thallus consisting of scattered or almost contiguous areoles and numerous soralia, which are rounded, flat, convex or weakly capitate, discrete or partly fused and forming a leprose crust. Soredia are green, but externally pale brown pigmented in some specimens (Kukwa et al., 2012). The species has been reported from Europe (Austria, Belgium, Croatia, France, Lux- embourg, Poland, Romania, Slovakia, Slovenia and Ukraine) and North America (Kukwa et al., 2012 and literature cited therein).

\# Chaenothecopsis vainioana (Nádv.) Tibell - 10: on Quercus robur, together with Anisomeridium polypori, leg. AS, det. PL (TU87247). Rather rare species in Estonia, all records are from wooded meadows and oak-dominated woodlands.

Cladonia monomorpha Aptroot, Sipman \& Herk - 4: on bryophytes growing on sandstone, AT (GSU), TLC: fumarprotocetraric acid; 10: on saxicolous bryophytes, MK 20531 (UGDA), TLC: fumarprotocetraric and protocetraric acids; AT (GSU). This is a member of a taxonomically difficult Cladonia pyxidata group and has not always been distinguished from C. pyxidata (Kowalewska et al., 2008 and literature cited therein), but recent molecular studies treat this species as a distinct taxon (Stenroos et al., 2019). The species is most similar to C. pyxidata and C. pocillum, from which it differs by the presence of bullate plates (commonly with whitish margins) inside and outside scyphi, and glomerulose apothecia (Aptroot et al., 2001; Kowalewska et al., 2008; Tsurykau \& Golubkov, 2015). Chemically similar C. chlorophaea and C. fimbriata differ by producing soredia. Cladonia monomorpha is widely distributed in Europe, being also known from North America, including Greenland (Kowalewska et al., 2008), and Asia (Mongolia, Turkey and Russian Arctic) (Kowalewska et al., 2008; Osyczka et al., 2011; Golubkov \& Tsurykau, 2017). Cladonia monomorpha has been reported previously from Estonia (Aptroot et al., 2005), but the specimens from a single locality (TU28247, TU30991, TU30992a) were redetermined as Cladonia pyxidata.

\# Didymocyrtis ramalinae (Roberge ex Desm.) Ertz, Diederich \& Hafellner - 3: on the thallus of Ramalina fastigiata growing on Padus avium, MK 20447 (UGDA). The finding represents the asexual stage of the fungus. The dimensions of hyaline, ellipsoid conidia are 5.5-6.5 $\times 3.5 \mu \mathrm{m}$. The fungus, mainly its asexual stage, is recorded from many countries in Europe but the species is also known in Africa and Australasia (Ertz et al., 2015).

Enchylium Limosum (Ach.) Otálora, P. M. Jørg. \& Wedin - 4: on sandstone, AS (TU86765, TU86767). The species is rather rare (this is the seventh record), and it belongs to the red-listed 
category Vulnerable according to the the latest version of the Red List of Estonia (Lõhmus et al., 2019).

Halecania viridescens Coppins \& P. James - 6: on wood of log, MK 20474 (UGDA), TLC: argopsin (major), norargopsin (minor), 'gracilenta unknown 1'. This is the second, but the first published record in Estonia. The species was previously found from Heinlaid islet in Hiiu County as growing on twig of Rhamnus cathartica (TU45760.a.), but because of the scarce material remained unreported. Halecania viridescens is usually sterile and characterized by small, fragile, usually punctiform or rarely confluent soralia (often with a brown pigment in the external soredia), and the presence of argopsin and 'gracilenta unknown 1' (Tønsberg, 1992; Kukwa \& Jabłońska, 2009). The species is rarely reported, but widespread and has been reported from several countries in Europe, North America, central America (Guatemala) and Africa (the Canary Islands) (Kukwa \& Jabłońska, 2009 and literature cited therein).

LECANORA PERSIMILIS (Th. Fr.) Arnold - 2: roadside trees, on Fraxinus excelsior, MK 20442a (UGDA). This is the second record of this species in Estonia, known previously from northern Estonia (Martin et al., 2011).

LECANORA SUBCARPINEA Szatala - 10: on Quercus robur, MK 20536 (UGDA), TLC: atranorin (major), psoromic acid (minor), unknown (trace). The disc of ascomata is slightly pruinose, $\mathrm{C}+$ yellow, apothecial margin $\mathrm{Pd}+$ yellow. The species is rare in Estonia (this is the fifth locality), the closest locality in Nedrema wooded meadow is ca 10 kilometres (Aptroot et al., 2005).

LECIDELLA ELAEOCHROMA f. SORALIFERA (Erichsen) D. Hawksw. - 3: on Fraxinus excelsior, MK 20449 (UGDA); leg. AS, det. MK (TU86789). This is a rarely reported sorediate form of a very common Lecidella elaeochroma (Tønsberg, 1992).

LEPRARIA RIGIDUla (B. de Lesd.) Tønsberg - 1: on Juniperus communis, MK 20435 (UGDA), TLC: atranorin, nephrosteranic acid. The presence of a rare fatty acid, nephrosteranic acid, and soredia with long projecting hyphae are diagnostic characters of this taxon. It is a rather common epiphytic species in open habitats in Europe but found also on other substrates and outside Europe (Tønsberg, 1992; Baruffo et al., 2006; Kukwa, 2006; Saag et al., 2009).
Lepraria vouauxi (Hue) R. C. Harris - 4: on sandstone, MK 20456, MK 20458 (UGDA); 9: together with L. finkii on Ulmus scabra, MK 20515 (UGDA); 12: on Acer platanoides, AS (TU87653). All specimens contain pannaric acid 6-methylester detected with TLC. The species is rather rare, known from less than ten localities in Estonia. Lepraria vouauxii grows on various substrates, but often on tree bark in open habitats (Tønsberg, 1992; Baruffo et al. 2006; Kukwa, 2006; Saag et al., 2009). Many records from South America were recently segregated as L. cryptovouauxii (Guzow-Krzemińska et al., 2019).

Lobaria PUlMONARIA (L.) Hoffm. - 12: on Quercus robur, AS (not collected). The species is protected in Estonia and was recently evaluated according to IUCN criteria as Vulnerable (Lõhmus et al., 2019). It was recorded growing on a single tree in Tõstamaa park.

OCHROLECHIA BAHUSIENSIS H. Magn. - 10: together with Lepra albescens (KC negative) on Quercus robur, MK 20532 (UGDA); 12: on Pinus sylvestris, MK 20550 (UGDA), TLC: gyrophoric acid, murolic acid complex, unidentified pigments. The species had ten localities in Estonia but is probably under-recorded due to similarities with several other Ochrolechia species. This is a widespread species in Europe which is mostly confined to lower altitudes, and found mainly on bark of deciduous trees in various types of ecosystems (Kukwa, 2011).

Ochrolechia szatalaensis Verseghy - 7: on Juniperus communis, MK 20505 (UGDA; UDB0779091). The cortex of apothecial margin in the Estonian specimen is not glassy at the base in sectioned apothecia, but white and thus more similar to O. upsaliensis (Kukwa, 2011). However, the nuITS sequences are one-to-one identical to the sequences of $O$. szatalaensis (MK811817, MK811903, MK811865, FR799244) deposited in GenBank. This is a frequent but scattered species in Estonia, however, as morphological characters of the specimen deviate from the known description, we still report it here.

Parmelia serrana A. Crespo, M. C. Molina \& D. Hawksw. - 6: on Betula pendula, leg. AS, det. AT \& AS (TU86826; UDB0778439); AT (GSU; verified by A. Thell), TLC of both collections: salazinic acid, atranorin and fatty acids. The 
population in Salupeaksi is a mixture of two cryptic species, $P$. ernstiae and $P$. serrana, which are realistically identifiable only by DNA sequences (Haugan \& Timdal, 2019; Tsurykau et al., 2019). We compared nuITS sequences and composition of lichen substances of three specimens, two of which corresponded to $P$. serrana and one to P. ernstiae (E. Ossowska, pers. comm.). The latter specimen is deposited in UGDA.

\# Pronectria ERYthrinella (Nyl.) Lowen. - 5: all records on Peltigera praetextata growing on mossy stone fence, AS (TU86773), AT (GSU), JM (BILAS). The species has less than ten scattered localities in Estonia.

\# Pronectria santessoni (Lowen \& D. Hawksw.) Lowen - 3: on Anaptychia ciliaris on Fraxinus excelsior, AS (TU87916), AT (GSU), both det. JM. The species has been found previously only once in Estonia (Martin et al., 2012). The characteristics of the specimens are in concordance with the protologue of the species (Lowen \& Hawksworth, 1986). The dimensions of the ascospores of TU87916 are 12.5-(13.96 \pm 1.05$)-16$ $\times 5-(5.8 \pm 0.59)-7 \mu \mathrm{m}(\mathrm{n}=13)$.

\# Sclerococcum homoclinellum (Nyl.) Ertz \& Diederich (syn. Dactylospora homoclinella (Nyl.) Hafellner) - 7: on Protoparmeliopsis muralis on granite, AS (TU86806; UDB0778820). This is the second record of this species from Estonia, previously reported as growing on Buellia griseovirens (Suija, 2005).

Sclerophora Pallida (Pers.) Y. J. Yao \& Spooner - 5: on Fraxinus excelsior, leg. AS, det. PL (TU86820); 6: RM (DAU600001114); PL (TU). This species is protected in Estonia and has recently been evaluated as Near Threatened in the latest version of the national Red List (Lõhmus et al., 2019).

\# Spirographa tricupulata (F. Berger \& E. Zimm.) Flakus, Etayo \& Miadlikowska (syn. Cor nutispora tricupulata F. Berger \& E. Zimm) - 11: on Physcia cf. tenella on willow twig, MK 20547 (UGDA). Spirographa tricupulata is characterized by having conidia composed of three equal arms, 4-5.2 $\times 2.4-3 \mu \mathrm{m}$, which are strongly swollen at the base and develop 1.2-1.5 $\mu \mathrm{m}$ long cilia at the ends (Zimmermann \& Berger, 2018). The conidia of the Estonian specimen have swollen, almost equal arms, $4 \times 2 \mu \mathrm{m}$ and with cilia c. $1.5 \mu \mathrm{m}$ long. So far, the species has been known only from Austria (Zimmermann \& Berger, 2018). This is the second Spirographa species besides $S$. lichenicola (D. Hawksw. \& Sutton) Flakus, Etayo \& Miadlikowska (syn. Cornutispora lichenicola D. Hawksw. \& B. Sutton) that is reported from Estonia (Aptroot et al., 2005).

\# Stigmidium solorinarium (Vain.) D. Hawksw. - 8: on Solorina sp. on limestone cliffs, AS (TU86805). This is the second record of this Solorina-specialized lichenicolous species in Estonia (Suija et al., 2009).

\# Trichonectria Rubefaciens (Ellis \& Everh.) Diederich \& Schoers - 10: on Parmelia sulcata, AT (not collected). This is the third locality for the species in Estonia. Trichonectria rubefaciens is one of those lichenicolous species that is easily recognizable in field because of characteristic reddish orange perithecia on the discoloured thalli of Parmelia species (Sérusiaux et al., 1999).

\# XanthoriICola Physciae (Kalchbr.) D. Hawksw. - 3: on Xanthoria parietina, AS (TU86790). The dematiaceous lichenicolous species has less than ten localities in Estonia but is probably under-recorded although it is one of the most easily recognizable species among lichenicolous fungi as the host apothecia turn black due to the infection. Microscopically, each blackened apothecium contains mycelium that forms conidiogenous area in the host hymenium near the surface of the apothecium. The conidiogenous area is characteristic for this fungus as it is formed by penicillate, short and brown, monophialidic conidiogenous cells. Brown, globose and warted conidia in dimensions of 3.5-6 $\mu \mathrm{m}$ that develop terminally on conidiogenous cells lie on the surface of the host apothecium (Hawksworth \& Punithalingam, 1973) giving apothecia a black appearance.

XylogRaPHA PARAllela (Ach.) Fr. - 10: on wood, together with Buellia griseovirens, Lecanora symmicta and Placynthiella icmalea, IJ (TU88412). This is the tenth record of the lignicolous species in Estonia.

\section{List of species on Tori sandstone outcrop}

The Tori Põrgu Landscape Reserve was created in 1959 to protect middle-Devonian sandstone bank and caves at the Pärnu river in south-western Estonia. The length of the bank is ca $400 \mathrm{~m}$ and its maximum height is $8.25 \mathrm{~m}$ being thus 
the most representative outcrop of this epoch in the East Baltic area (Fig. 2). There are three caves created by the stream waters eroding the sandstone bank and expanded by human activities. The largest cave is called "Tori Põrgu" ("Tori Hell" in translation) as in the Estonian folklore, this was the lodging of horned family, namely Vanapagan ("The Old Heathen", also known as "The Old Devil" or "The Old Empty One") and others (Laugaste \& Liiv, 1970).

Systematic studies of lichens on Devonian sandstone cliffs are scarce in Estonia. There is one diploma work (Tenson, 1970), and one species inventory (Ingerpuu \& Suija, 2010) dealing with sandstone lichens in central and eastern parts of Estonia. The list here is the first from the southwestern part of Estonia, including 26 species, all recorded as growing directly on sandstone. The number of species is close to that of Kallaste sandstone outcrop in eastern Estonia (28 species; Ingerpuu \& Suija, 2010). The list includes three notable species, Cladonia monomorpha, Enchylium limosum and Lepraria vouauxii (see the list above).

Athallia holocarpa (Hoffm.) Arup, Frödén \& Søchting - AS (TU86768).

Bacidia Bagliettoana (A. Massal. \& De Not.) Jatta - AS (TU86772).

BAEOMYCES RUfUS (Huds.) Rebent. - AS (TU89609). In some spots, the specimens of Baeomyces were surrounded by the black mycelial network. Sphaerellothecium conioides is the

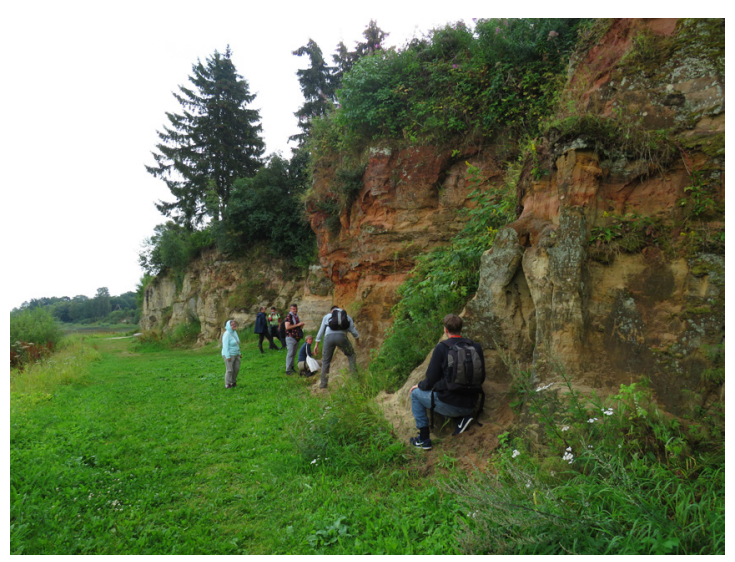

Fig. 2. The sandstone outcrop of Tori Põrgu Landscape Reserve. Photo: Jurga Motiejūnaitè only species that has such dark-brown vegetative hyphae and grows on $B$. rufus (Roux $\&$ Triebel, 1994). However, no ascomata were developed and therefore the identity of the fungus remained unclear.

Bilimbia SABUletorum (Schreb.) Arnold - AS (TU86766).

Chaenotheca furfuracea (L.) Tibell - AS.

Cladonia chlorophaea (Flörke ex Sommerf.) Spreng. - AS (TU86825; UDB0778437); MK 20457 (UGDA); AT (GSU).

Cladonia monomorpha Aptroot, Sipman \& Herk - AT (GSU).

Enchylium Limosum (Ach.) Otálora, P. M. Jørg. \& Wedin - AS (TU86767; TU86765).

EVERNIA PRUNASTRI (L.) Ach. - AS.

Flavoplaca citrina (Hoffm.) Arup, Frödén \& Søchting - AS (TU86764).

HAEMATOMMA OCHROLEUCUM (Neck.) J. R. Laundon - MK 20463 (UGDA).

LECIDELLA CARPATHICA Körb. - RM (DAU 600001111). LEPRARIA FINKII (B. de Lesd.) R. C. Harris (syn. L. lobificans auct.) - MK 20459 (UGDA).

LEPRARIA INCANA (L.) Ach. - MK 20467 (UGDA).

LEPRARIA VOUAUXII (Hue) R. C. Harris - MK 20456; MK 20458 (UGDA).

LEPROPLACA CHRYSODETA (Vain. ex Räsänen) J.

R. Laundon - AS (TU86800); MK 20460 (UGDA).

PaRmelia SUlCata Taylor - AS.

Peltigera canina (L.) Willd. - MK 20464 (UGDA). PElTigera Didactyla (With.) J. R. Laundon - AS. Peltigera membranacea (Ach.) Nyl. - MK 20465 (UGDA).

Peltigera neckeri Hepp ex Müll. Arg. - AS (TU86770); MK 20466 (UGDA).

Peltigera praetextata (Flörke ex Sommerf.) Zopf - AS.

Peltigera Rufescens (Weiss) Humb. - AS (TU86769).

Phlyctis ARgena (Ach.) Flot. - MK 20461 (UGDA). RAMALINA FARINACEA (L.) Ach. - AS (TU86771); MK 2045 (UGDA).

RAmalina POLLINARIA (Westr.) Ach. - MK 20455 (UGDA).

\section{List of species in the oak wood in Naissoo Nature Reserve}

The Naissoo Nature Reserve (115.71 ha) is located in south-western part of Estonia and was created in 1964 to protect old oak woods and spruce forests. The oldest oaks (Quercus robur) 
in the area are 230 years old. The calciferous meadows (alvars) are less represented in the area. The oakwoods are probably former wooded pastures and wooded meadows that are now overgrown due to the cessation of mowing and grazing (Naissoo looduskaitseala ...). In some places, the remnants of limestone fences and piles of stones are visible under the oak trees.

The list is based on the collective survey effort made during 1.5 hours in a limited area in eastern part of the reserve. The species list includes 95 species, of which 83 are lichenized, 11 lichenicolous-algicolous fungi, and one is a non-lichenized calicioid fungus. During the limited timeframe, the participants found four rare species (Lecanora subcarpinea, Ochrolechia bahusiensis, Trichonectria rubefaciens and Xylographa parallela), and two species new to Estonia (Candelariella efflorescens and Cladonia monomopha). In addition, participants recorded several Woodland Key Habitat (WKH) species that grow mainly on oaks in the area. No collector's initials are indicated for the common species that were registered by most of the participants.

! Acrocordia gemmata (Ach.) A. Massal. - on Quercus robur, PL (TU87927).

! AlyXoria VARIa (Pers.) Ertz \& Tehler - on $Q$. robur, MK 20527 (UGDA); AS (TU86801).

ANAPTYCHIA CILIARIS (L.) Körb. - on Q. robur.

ANISOMERIDIUM POLYPORI (Ellis \& Everh.) M. E. Barr - on Q. robur, AS (TU87247.b).

ARTHONIA MEDIELLA Nyl. - on Q. robur, MK 20520 (UGDA); on Picea abies, MK 20526 (UGDA); PL (TU87926).

ARthonia RADiATA (Pers.) Ach. - on twig of $Q$. robur, MK 20525 (UGDA).

ARTHONIA SPADICEA Leight. - on Q. robur, PL.

ARTHONIA VINOSA Leight. - on Q. robur.

AsPiCILIA CONTORTA subsp. HOFFMANNIANA S. Ekman \& Fröberg - on limestone, IJ.

\# Athelia ARachnoidea (Berk.) Jülich - on Xanthoria parietina.

BACIDIA ARCEUTINA (Ach.) Arnold - on Q. robur, AS.

BiATORA EFFLORESCENS (Hedl.) Räsänen - on $Q$. robur, MK 20533 (UGDA).

Bilimbia sabuletorum (Schreb.) Arnold - on mosses on limestone, IJ (TU88410).

BuEllia GRISEOVIRENS (Turner \& Borrer ex Sm.) Almb. - on lignum, IJ (TU88409.c); on lignum, IJ (TU88412.b); on Q. robur, PL; on Juniperus communis, AS.
Calicium glaucellum Ach. - on lignum of $Q$. robur log, PL (TU87929).

Calicium Salicinum Pers. - on Q. robur, PL.

CALICIUM VIRIDE Pers. - on Q. robur, PL.

Candelariella efflorescens R. C. Harris \& W. R. Buck (aggregate) - on Q. robur, leg. AT, det. MK (GSU).

Candelariella Xanthostigma (Ach.) Lettau - on Q. robur, MK 20535 (UGDA); PL.

! ChaEnotheca BRAchypoda (Ach.) Tibell - on lignum of $Q$. robur log, PL.

Chaenotheca chrysocephala (Turner ex Ach.) Th. Fr. - on Pinus sylvestris, IJ.

Chaenotheca trichialis (Ach.) Th. Fr. - on P. sylvestris, IJ; on $Q$. robur, PL.

\# Chaenothecopsis vainioana (Nádv.) Tibell - on Q. robur, leg. AS, det. PL (TU87247.a); PL (TU87928).

Cladonia Chlorophaea (Flörke ex Sommerf.) Spreng. (aggregate) - IJ.

Cladonia CONIOCRAEA (Flörke) Spreng. - on lignum, IJ (TU88408.a); on mosses on limestone, IJ (TU88411.b).

Cladonia fimbriata (L.) Fr. - on Q. robur, IJ.

Cladonia monomorhPa Aptroot, Sipman \& Herk - on saxicolous bryophytes, MK 20531 (UGDA); AT (GSU).

Cladonia OCHROCHLORA Flörke - on mosses on limestone, AS (TU87246.a); on base of Betula, IJ (TU88405); on Juniperus communis, AS.

Cladonia POCIllum (Ach.) Grognot - on mosses on limestone, IJ (TU88407).

Coenogonium Pineti (Schrad. ex Ach.) Lücking \& Lumbsch - on $Q$. robur AS.

EVERNIA PRUNASTRI (L.) Ach. - on Q. robur.

\# Heterocephalacria PHysciacearum (Diederich) Millanes \& Wedin - on thallus of Physcia adscendens, AS.

HYPOCENOMYCE SCALARIS (Ach.) M. Choisy - on old Betula, IJ (TU88406.b).

Hypogymnia Physodes (L.) Nyl. - on $Q$. robur, $B$. pendula.

HYPOGYMNIA TUBULOSA (Schaer.) Hav. - on Q. robur. \# Intralichen sp. - in apothecia of Lecanora, AS (TU86802).

LATHAGRIUM FUSCOVIRENS (With.) Otálora, P. M. Jørg. \& Wedin - on mosses on limestone, JM (TU86797.a); IJ.

LECANORA CARPINEA (L.) Vain. - on twig of Q. robur, MK 20525a (UGDA); on Q. robur, MK 20536a (UGDA).

LECANORA CHLAROTERA Nyl. - on Q. robur. 
LECANORA EXPAllens Ach. - on Q. robur, PL.

LECANORA PULICARIS (Pers.) Ach. - on B. pendula, IJ.

LECANORA STROBILINA (Spreng.) Kieff. - on twig of Q. robur, MK 20522 (UGDA).

LECANORA SUBCARPINEA Szatala - on $Q$. robur, MK 20536 (UGDA).

LeCANORA symmicta (Ach.) Ach. - on lignum, IJ (TU88412.c).

Lecidella elaeochroma (Ach.) M. Choisy - all on Q. robur, MK 20521 (UGDA); MK 20530a (UGDA); MK 20537 (UGDA).

LECIDELLA FLAVOSOREDIATA (Vězda) Hertel \& Leuckert - on Q. robur, MK.

LEPRA ALBESCENS (Huds.) Hafellner (syn. Pertusaria albescens (Huds.) M. Choisy \& Werner) - on Q. robur, MK 20532 (UGDA).

LEPRA AMARA (Ach.) Hafellner (syn. Pertusaria amara (Ach.) Nyl.) - on lignum, IJ (TU88408.b).

LEPRARIA EBURNEA J. R. Laundon - both on $Q$. robur, MK 20539 (UGDA); MK 20541a (UGDA).

LEPRARIA FINKII (B. de Lesd.) R. C. Harris - on $Q$. robur, MK 20540 (UGDA).

LEPRARIA INCANA (L.) Ach. - both on Q. robur, MK 20541 (UGDA); MK 20542 (UGDA).

\# Lichenoconium Xanthoriae M. S. Christ. - on Xanthoria parietina, AT (GSU).

\# Marchandiomyces aURANTIACUs (Lasch) Diederich \& Etayo - on Physcia tenella, AS.

Melanelixia glabratula (Lamy) Sandler \& Arup - on Q. robur.

Melanelixia subaurifera (Nyl.) O. Blanco, A. Crespo, Divakar, Essl., D. Hawksw. \& Lumbsch - on Q. robur.

Melanohalea exasperatula (Nyl.) O. Blanco, A. Crespo, Divakar, Essl., D. Hawksw. \& Lumbsch - on Q. robur.

Micarea misella (Nyl.) Hedl. - on lignum, IJ (TU88409.a).

\# Microcalicium disseminatum (Ach.) Vain. - on Q. robur, PL (TU87930).

+ Mrcocalicium subtile (Pers.) Szatala - on lignum, IJ (TU88409.b); on lignum of $Q$. robur, PL.

\# Nesolechia oxyspora (Tul.) A. Massal. - all on thalli of Parmelia sulcata, AT; growing on twig of Salix, MK 20523 (UGDA), on twig of Q. robur, AS (TU86774).

OCHROLECHIA ARBOREA (Kreyer) Almb. - on twig of Q. robur, MK 20524 (UGDA).

OCHROLECHIA BAHUSIENSIS H. Magn. - on Q. robur, MK 20532 (UGDA).
Opegrapha vulgata (Ach.) Ach. - on Q. robur, PL (TU87931).

Pachyphiale fagicola (Arnold) Zwackh - on $Q$. robur, MK 20535a (UGDA).

Parmelia ERnstiae Feuerer \& A. Thell - on $Q$. robur, MK 20529 (UGDA).

Parmelia sulcata Taylor - on B. pendula.

Peltigera canina (L.) Willd. - on Q. robur, PL, det. IJ (TU87932).

Peltigera NeCKeri Hepp ex Müll. Arg. - on ground over mosses, IJ (TU89562; UDB0779902).

Peltigera PRAETEXTATA (Flörke ex Sommerf.) Zopf - on mosses in stone pile, AS.

Pertusaria coccodes (Ach.) Nyl. - both on $Q$. robur, MK 20532a (UGDA); MK 20534 (UGDA).

Pertusaria CoRonata (Ach.) Th. Fr. - on Q. robur, $\mathrm{PL}$. In the field $\mathrm{UV}+$ orange, $\mathrm{K}+$ yellow, then orange.

PeRTUSARIA Leioplaca DC. - on $Q$. robur.

PhLYCTIS ARGENA (Spreng.) Flot. - all on Q. robur, MK 20528 (UGDA); MK 20530 (UGDA); MK 20538 (UGDA); AS (TU86808).

PhysCIA ADSCENDENS (Fr.) H. Olivier - on Q . robur.

Physcia Aipolia (Ehrh. ex Humb.) Fürnr. - on Q. robur.

Physcia Stellaris (L.) Nyl. - on Q. robur.

Physcia tenella (Scop.) DC. - on Q. robur.

PHYSCONIA DISTORTA (With.) J. R. Laundon - on Q. robur.

PHYSCONIA PERISIDIOSA (Erichsen) Moberg - on Q. robur.

Placynthiella icmalea (Ach.) Coppins \& P. James - on lignum, IJ (TU88412.d); on $\log$ of $Q$. robur, on wood, PL.

Platismatia glauca (L.) W. L. Culb. \& C. F. Culb. - on $Q$. robur.

PolyCAUliona POlYCARPa (Hoffm.) Frödén, Arup \& Søchting - on $Q$. robur.

PseUdeVERnia FURFURACEA (L.) Zopf - on $Q$. robur.

RAMALINA FASTIGIATA (Pers.) Ach. - on Q. robur.

Scytinium Lichenoides (L.) Otálora, P. M. Jørg. $\&$ Wedin - all records on mosses on limestone, JM (TU86797.b); AS (TU87246.b); IJ (TU88411.a).

Toniniopsis subincompta (Nyl.) Kistenich, Timdal, Bendiksby \& S. Ekman (syn. Bacidia subincompta (Nyl.) Arnold) - on Q. robur, PL.

TRAPEliopsis FleXUOSA (Fr.) Coppins \& P. James - on base of Betula, IJ (TU88406.a); on $J$. communis.

\# Tremella hypogymniae Diederich \& M. S. Christ. - on Hypogymnia physodes, JM (TU86796). 
\# Trichonectria Rubefaciens (Ellis \& Everh.) Diederich \& Schroers - on thallus of Parmelia sulcata, AT.

VERRUCARIA DOLOSA Hepp - on limestone, AS (TU86823; UDB0778442).

\# Vouauxiella lichenicola (Linds.) Petr. \& Syd. - on apothecia of Lecanora chlarotera, AS.

VULPICIDA PINASTRI (Scop.) J.-E. Mattsson \& M. J. Lai - on Q. robur.

XANTHOPARMELIA CONSPERSA (Ach.) Hale - on granite stone, AS.

XANTHORIA PARIETINA (L.) Th. Fr. - on Q. robur.

XYlographa PARAllela (Ach.) Fr. - on lignum, IJ (TU88412.a).

\section{ACKNOWLEDGEMENTS}

Arne Thell (Lund) and Emilia Ossowska (Gdansk) are thanked for confirming identity of Parmelia serrana and P. ernstiae respectively. Rasmus Puussepp (Tartu) is thanked for DNA work. Ede Oja, Tiina Randlane, Andres Saag, Maarja Nõmm, Magdalena Kosecka, Sigrid Maasen and Indrek Tammekänd are thanked for participation. The financial support for the meeting was provided by the Gambling Tax Council and by bilateral exchange programme between Academies of Sciences (enabling participation of $\mathrm{JM}$ and MK). The financial support of AS was provided by the European Regional Development Fund (Centre of Excellence EcolChange).

\section{REFERENCES}

Anonymous. 2017. Habitat Classification, Selection Guide, Arrangement of Protection and Conclusion of the Contract for the Protection of the Habitat and Specified Basis for Calculating the Right of Use Fee. Available online: https://www.riigiteataja. ee/akt/ 115092017008 (accessed March 2020).

Aptroot, A., Czarnota, P., Jüriado, I., Kocourková, J., Kukwa, M., Lõhmus, P., Palice, Z., Randlane, T., Saag, L., Sérusiaux, E., Sipman, H., Sparrius, L. B., Suija, A. \& Thüs, H. 2005. New or interesting lichens and lichenicolous fungi found during the 5 th IAL Symposium in Estonia. Folia Cryptogamica Estonica 41: 13-22.

Aptroot, A., Sipman, H. J. M. \& van Herk, C. M. 2001. Cladonia monomorpha, a neglected cup lichen from Europe. The Lichenologist 33: 271-283. https://doi.org/10.1006/lich.2001.0332

Baruffo, L., Zedda, L., Elix, J. A. \& Tretiach, M. 2006. A revision of the lichen genus Lepraria s. lat. in Italy. Nova Hedwigia 83: 387-429. https://doi. org/10.1127/0029-5035/2006/0083-0387
Ertz, D., Diederich, P., Lawrey, J. D., Berger, F., Freebury, C. E., Coppins, B., Gardiennet, A. \& Hafellner, J. 2015. Phylogenetic insights resolve Dacampiaceae (Pleosporales) as polyphyletic: Didymocyrtis (Pleosporales, Phaeosphaeriaceae) with Phoma-like anamorphs resurrected and segregated from Polycoccum (Trypetheliales, Polycoccaceae fam. nov.). Fungal Diversity 74(1): 53-89. https://doi.org/10.1007/s13225-015-0345-6

Gasparyan, A. \& Sipman, H. J. M. 2016. The epiphytic lichenized fungi in Armenia: Diversity and conservation. Phytotaxa 281(1): 1-68. https://doi. org/10.11646/phytotaxa.281.1.1

Golubkov, V. \& Tsurykau, A. 2017. Contribution to the knowledge of Cladonia in the Russian Arctic. Graphis Scripta 29(1-2): 8-11.

Guzow-Krzemińska, B., Jabłońska, A., Flakus, A., Rodriguez-Flakus, P., Kosecka, M. \& Kukwa, M. 2019. Phylogenetic placement of Lepraria cryptovouauxii sp. nov. (Lecanorales, Lecanoromycetes, Ascomycota) with notes on other Lepraria species from South America. MycoKeys 53: 1-22. https:/ / doi.org/ 10.3897/mycokeys.53.33508

Halonen, P., Kukwa, M., Motiejūnaitè, J., Lõhmus, P. $\&$ Martin, L. 2000. Notes on lichens and lichenicolous fungi found during the XIV Symposium of Baltic Mycologists and Lichenologists in Järvselja, Estonia. Folia Cryptogamica Estonica 36: 17-21.

Haugan, R. \& Timdal, E. 2019. The morphologically cryptic lichen species Parmelia ernstiae and P. serrana new to Norway. Graphis Scripta 31(2): 5-13.

Hawksworth, D. L. \& Punithalingam, E. 1973. New and interesting microfungi from Slapton, South Devonshire: Deuteromycotina. Transactions of the British Mycological Society 61: 57-69.

Holien, H., Frisch, A., Jonsson, F., Klepsland, J. T., Millanes, A. M., Motiejūnaitè, J., Prieto, M., Pykälä, J., Suija, A., Tsurykau, A., Westberg, M. \& Bendiksby, M. 2016. Interesting lichenized and Lichenicolous fungi found during the Nordic Lichen Society excursion in Nord-Trøndelag, Norway 2015. Graphis Scripta 28: 40-49.

Ingerpuu, N. \& Suija, A. 2010. Tamme ja Kallaste liivakivipaljandite elupaikade loodusväärtuste uuring: samblad ja samblikud. Species inventory commissioned by Keskkonnaamet [in Estonian].

Ismailov A. B., Urbanavichus, G. P., Yakovchenko, L. S. \& Urbanavichene, I. N. 2017. The genus Candelariella (Candelariaceae, Candelariales) in the lichen flora of the Caucasus. Botanicheskii Zhurnal 102(6): 780-796. https://doi.org/10.1134/ S0006813617060059

Kõljalg, U., Nilsson, R. H., Abarenkov, K., Tedersoo, L., Taylor, A. F. S., Bahram, M., Bates, S. B., Bruns, T. D., Bengtsson-Palme, J., Callaghan, T. M., Douglas, B., Drenkhan, T., Eberhardt, U., Dueñas, M., Griffith, T. G. W., Hartmann, M., Kirk, P. M., Kohout, P., Larsson, E., Lindahl, B. D., Lücking, R., Martín, R. M. P., Matheny, P. B., Nguen, N. H., Niskanen, T., Oja, J., Peay, K. G., 
Peintner, U., Peterson, M., Põldmaa, K., Saag, L., Saar, I., Schüssler, A., Scott, J. A., Senés, C., Smith, M. E., Suija, A., Taylor, D. L., Telleria, T., Weiss, M. \& Larsson, K.-H. 2013. Towards a unified paradigm for sequence-based identification of fungi. Molecular Ecology 22: 5271-5277. https:/ / doi.org/10.1111/mec. 12481

Kowalewska, A., Kukwa, M., Ostrowska, I., Jabłońska, A., Oset, M. \& Szok, J. 2008. The lichens of the Cladonia pyxidata-chlorophaea group and allied species in Poland. Herzogia 21: 61-78.

Kukwa, M. 2000. Lepraria lesdainii, a lichen species new to Poland. Fragmenta Floristica et Geobotanica 45: 534-536.

Kukwa, M. 2006. The lichen genus Lepraria in Poland. The Lichenologist 38: 293-305. https:/ / doi. org/ 10.1017/S0024282906005962

Kukwa, M. 2011. The lichen genus Ochrolechia in Europe. Fundacja Rozwoju Uniwersytetu Gdańskiego, 309 pp.

Kukwa, M. \& Czarnota, P. 2008. Nowe stanowiska Botryolepraria lesdainii (zlichenizowane Ascomycota) w Polsce. Fragmenta floristica et geobotanica Polonica 15(2): 342-345.

Kukwa, M. \& Jabłońska, A. 2009. New records of two crustose sorediate lichens from central Europe. Mycotaxon 107: 375-381. https://doi. org/10.5248/107.375

Kukwa, M., Łubek, A., Szymczyk, R. \& Zalewska, A. 2012. Seven lichen species new to Poland. Mycotaxon 120: 105-118. https://doi. org/10.5248/120.105

Kümmerling, H \& Leuckert, C. 1993. Chemische Flechtenanalysen VIII. Lepraria lesdainii (Hue) R. C. Harris. Nova Hedwigia 56(3-4): 483-490.

Laugaste, E. \& Liiv, E. 1970. Muistendid Vanapaganast [In Estonian]. Eesti Raamat, Tallinn.

Laundon, J. R. 1992. Lepraria in the British Isles. The Lichenologist 24: 315-350. https://doi. org/10.1017/S002428299200046X

Lõhmus, P., Marmor, L., Jüriado, I., Suija, A., Oja, E., Degtjarenko, P. \& Randlane, T. 2019. Red List of Estonian lichens: Revision in 2019. Folia Cryptogamica Estonica 56: 63-76. https://doi. org/ 10.12697/fce.2019.56.07

Lowen, R. \& Hawksworth, D. L. 1986. Nectriella santessonii, a new lichenicolous pyrenomycete with an Acremonium anamorph. The Lichenologist 18: 321-328. https://doi.org/10.1017/ S0024282986000518

Martin, L., Randlane. T. \& Martin, J. 2011. Lichens and their substrate preferences on the Pakri Peninsula (Northwest Estonia). Folia Cryptogamica Estonica 48: 45-58.

Martin, L., Suija, A., Schmeimann, M., Leppik, E. \& Pykälä, J. 2012. New Estonian records and amendments: Lichenized and lichenicolous fungi. Folia Cryptogamica Estonica 49: 93-96. https:// doi.org/10.12697/fce.2013.50.16
Naissoo looduskaitseala kaitsekorralduskava 2014 2023 [In Estonian]. Available at https://www. keskkonnaamet.ee/sites/default/files/kaitse_ planeerimine/naissoo_lka_kkk_2014-2023.pdf.

Orange, A., James, P. W. \& White, F. J. 2001. Microchemical Methods for the Identification of Lichens. British Lichen Society. 101 pp.

Osyczka, P., Yazici, K. \& Aslan, A. 2011. Note on Cladonia species (Lichenized Ascomycota) from Ardahan province (Turkey). Acta Societatis Botanicorum Poloniae 80(1): 59-62. https://doi. org/10.5586/asbp.2011.008

Randlane, T. \& Saag, A. (eds) 1999. Second checklist of lichenized, lichenicolous and allied fungi of Estonia. Folia Cryptogamica Estonica 35: 1-132.

Roux, C. \& Triebel, D. 1994. Révision des espèces de Stigmidium et de Sphaerellothecium (champignons lichénicoles non lichénisés, Ascomycetes) correspondant à Pharcidia epicymatia sensu Keissler ou à Stigmidium schaereri auct. Bulletin de la Société Linnéenne de Provence 45: 451-542.

Saag, L., A., Saag, A. \& Randlane, T. 2009. World survey of the genus Lepraria (Stereocaulaceae, lichenized Ascomycota). The Lichenologist 41: 25-60. https://doi.org/10.1017/ S0024282909007993

Sérusiaux, E., Diederich, P., Brand, A. M. \& van den Boom, P. 1999. New or interesting lichens and lichenicolous fungi from Belgium and Luxembourg. VIII. Lejeunia 162: 1-95.

Stenroos, S., Pino-Bodas, R., Hyvönen, J., Lumbsch, H. T. \& Ahti, T. 2019. Phylogeny of the family Cladoniaceae (Lecanoromycetes, Ascomycota) based on sequences of multiple loci. Cladistics 35: 351-384. https://doi.org/10.1111/cla.12363

Suija, A. 2005. Lichenicolous fungi and lichens in Estonia I. Ascomycota. Nova Hedwigia 80(12): 247-267. https://doi.org/10.1127/00295035/2005/0080-0247

Suija, A., Czarnota, P., Himelbrant, D., Jüriado, I., Kukwa, M., Lõhmus, P. \& Motiejūnaitè, J. 2009. New Estonian records: lichenized and lichenicolous fungi. Folia Cryptogamica Estonica 46: 83-86.

Tedersoo, L., Jairus, T., Horton, B. M., Abarenkov, K., Suvi, T., Saar, I. \& Kõljalg, U. 2008. Strong host preference of ectomycorrhizal fungi in a Tasmanian wet sclerophyll forest as revealed by DNA barcoding and taxon-specific primers. New Phytologist 180(2): 479-490. https://doi. org/10.1111/j.1469-8137.2008.02561.x

Tenson, R. 1970. Devoni liivakivipaljandite lihhenofloora ja selle seos ökoloogiliste tingimustega [Lichen flora of Devonian sandstone outcrops and its relation to ecological conditions]. Diploma work [In Estonian].

Thell, A., Alstrup, A., Arup, U., Bendiksby, M., Czarnota, P., Feuerer, T., Haugan, R., Kärnefelt, I., Klepsland, J. T., Kukwa, M., Launis, A., Millanes, A. M., Motiejūnaite, J., Nordin, A., Prieto, 
M., Pykälä, J., Seaward, M. R. D., Timdal, E., Tsurykau, A., Vitikainen, O. \& Westberg, M. 2014. New or interesting lichens and lichenicolous fungi from the Vadstena area, Östergötland, Sweden. Graphis Scripta 26: 15-33.

Tønsberg, T. 1992. The sorediate and isidiate, corticolous, crustose lichens in Norway. Sommerfeltia 14: 1-331.

Tsurykau, A., Bely, P., Golubkov, V., Persson, P.-E. \& Thell, A. 2019. The lichen genus Parmelia (Parmeliaceae, Ascomycota) in Belarus. Herzogia 32: 375-384. https://doi.org/10.13158/ heia.32.2.2019.375

Tsurykau, A. \& Golubkov, V. 2015. The lichens of the Cladonia pyxidata-chlorophaea complex in Belarus. Folia Cryptogamica Estonica 52: 63-71. https:/ / doi.org/10.12697/fce.2015.52.08

Tønsberg, T. 1992. The sorediate and isidiate, corticolous, crustose lichens in Norway. Sommerfeltia 14: 1-331.
Voitk, A., Saar, I., Lodge, D. J., Boertmann, D., Berche, S. M. \& Larsson, E. 2020. New species and reports of Cuphophyllus from northern North America compared with related Eurasian species. Mycologia 112(2): 438-452. https://doi.org/10.1080 /00275514.2019.1703476

Westberg, M. 2007. Candelariella (Candelariaceae) in western United States and northern Mexico: the polysporous species. The Bryologist 110: 375-390. https://doi.org/10.1639/00072745(2007)110[375:CCIWUS]2.0.CO;2

Westberg, M. \& Clerc, P. 2012. Five species of Candelaria and Candelariella (Ascomycota, Candelariales) new to Switzerland. MycoKeys 3: 1-12. https://doi.org/10.3897/mycokeys.3.2864

Zimmermann, E. \& Berger, F. 2018. Beitrag zur lichenicolen Mycobiota Österreichs - Funde aus den Tiroler Alpen I. Herzogia 31: 732-762. https:/ / doi.org/10.13158/heia.31.1.2018.732 